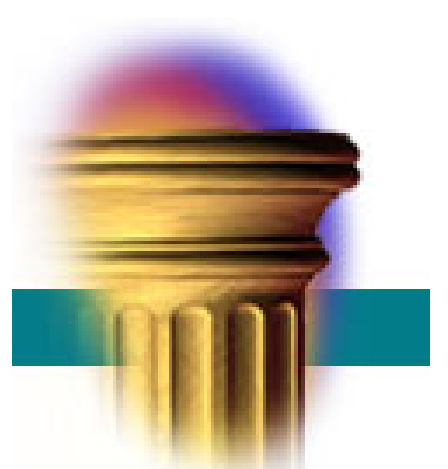

$\begin{array}{ll}O_{0} & \begin{array}{l}\text { Externalities in securities clearing and } \\ \text { settlement: Should securities CCPs clear }\end{array} \\ \text { E } & \text { trades for everyone? }\end{array}$

Sam Schulhofer-Wohl

\title{
March 2021
}

PDP 2021-02

https://doi.org/10.21033/pdp-2021-02

${ }^{*}$ Working papers are not edited, and all opinions and errors are the responsibility of the author(s). The views expressed do not necessarily reflect the views of the Federal Reserve Bank of Chicago or the Federal Reserve System. 
Externalities in securities clearing and settlement: Should securities CCPs clear trades for everyone?

Sam Schulhofer-Wohl*

Federal Reserve Bank of Chicago

March 19, 2021

\begin{abstract}
The architecture of securities clearing and settlement in the United States creates an externality: Investors do not always bear the full cost of settlement risk for their trades and can impose some of these costs on the brokerages where they are customers. When markets are volatile and settlement risk is high, this externality can result in too much or too little trading relative to the efficient level, because investors ignore trading costs but brokerages may refuse to allow investors to trade. Both effects were evident during the recent volatility in GameStop stock. Alternative approaches for clearing customer trades that are used in derivatives markets would eliminate the externality. I examine the potential benefits and costs of different approaches for clearing customer securities trades as well as implications for the U.S. Treasury market, where there have been calls to investigate the costs and benefits of expanded clearing of customer trades, and the relationship to faster equities settlement.
\end{abstract}

\footnotetext{
${ }^{*}$ The views expressed herein are those of the author and not necessarily those of the Federal Reserve Bank of Chicago or the Federal Reserve System. I thank Marta Chaffee, Vic Chakrian, Alessandro Cocco, Michael Fleming, Frank Keane, Spence Krane, Ketan Patel, Anna Paulson, Maggie Sklar, and Robert Steigerwald for helpful comments.
} 


\section{Introduction}

When people trade shares of stock in the United States, money and shares do not change hands immediately. Instead, after a trade takes place, the buyer has two business days to deliver the money, and the seller has two business days to deliver the shares. This system allows people to trade more quickly, because they need not pause to gather money and shares before trading. ${ }^{1}$ But it creates settlement risk. If two days pass and the buyer defaults on the obligation to deliver the cash, the seller will be stuck holding the shares - a bad result for the seller if the stock price has fallen in the meantime. The buyer may likewise worry that the seller could default on the obligation to deliver shares whose price has risen. A similar risk arises in the market for Treasury securities, though those trades typically settle in one business day. In general, settlement risk in the U.S. securities markets is the risk that a trader's counterparty will default on completing a transaction, requiring the trader to incur a cost to replace the transaction at current market prices. ${ }^{2}$ Settlement risk is higher when the risk of default ${ }^{3}$ is elevated and when market prices are more volatile, increasing the likely difference between the original transaction price and the price of any replacement trade.

The securities markets have developed methods to mitigate settlement risk, but, importantly, the buyer and seller typically do not directly bear the cost of mitigating the risk associated with each trade. Rather, buyers and sellers are usually customers of brokerage firms, and it is their brokers that must exchange the money and securities and pay the cost of managing

\footnotetext{
${ }^{1}$ Delayed settlement also reduces the size of cash flows needed for securities settlement by allowing the netting of offsetting cash flows for transactions that take place on the same day but not simultaneously. See Depository Trust \& Clearing Corp. (2021) and Monahan (2019).

${ }^{2}$ Settlement risk can also include principal risk, which is the risk that a trader will perform their part of the bargain but receive nothing in return, losing the full value of the transaction (Committee on Payments and Market Infrastructure, 2016). Principal risk has largely been eliminated in U.S. securities settlements through the use of delivery-versus-payment systems, which condition the transfer of securities on the transfer of money and vice versa. ${ }^{3}$ Securities market participants distinguish between settlement failures due to operational problems and settlement failures due to defaults. Operational failures are typically addressed by different mechanisms, such as fails charges.
} 
settlement risk. Brokerages can recover the average cost of risk management from their customers by charging various account and trading fees or as part of an overall package of financial services. But if a particular trade has above-average settlement risk, such as when market prices are unusually volatile, the infrastructure and regulations of the U.S. securities markets make it difficult for brokerages to charge that above-average cost to their customers.

In consequence, settlement risk in securities trades is subject to a classic externality: An investor who decides whether to trade does not always bear the full cost of this action and may impose some of the cost on a third party, the brokerage. This paper argues that when markets are volatile and settlement risk is expensive to manage, the externality can result in either too much or too little trading, relative to what would be efficient for the financial system as a whole. Customers may tend to trade more than is efficient during volatile times, potentially amplifying the volatility, because they do not pay the full cost of settlement risk management for their trades at these times. However, when customers' trades can create higher costs of settlement risk management than a brokerage is prepared to pay, the brokerage's main option in the moment is to stop such trades altogether, which can result in less than the efficient volume of trades. (Before the stress arises, brokerages can also choose the degree to which they prepare for it, such as by maintaining larger capital and liquidity buffers than the regulatory minimums.)

Recent stock market events illustrate this externality. In January 2020, the price of GameStop Corp. stock rose and became extremely volatile amid a "squeeze" on hedge funds that had sold the stock short. Even though the volatile price meant that settlement risk was elevated, trading volumes soared as investors sought to capitalize on the rising price (Banerji, Chung, and McCabe, 2021). But brokerages were required to post large amounts of collateral to a clearinghouse, the National Securities Clearing Corp. (NSCC), to cover the settlement risk on 
their customers' trades. The sudden calls for cash challenged some brokerages. To avoid even larger margin calls, these brokerages announced that they were temporarily stopping their customers from buying GameStop shares. ${ }^{4}$ Brokerages applied these restrictions even to customers who already had enough cash in their accounts to pay for the purchase, because under current regulations, a brokerage cannot use its customers' funds to cover margin calls associated with settlement risk on the customers' trades. $^{5}$

The externality arises from the design of the clearinghouses, or central counterparties (CCPs), that handle stock and bond trades. CCPs are specialized financial institutions that step into the middle of transactions in a market to provide each participant with a guarantee that the other participants will fulfill the commitments they have made by trading (Cox and Steigerwald, 2017). In the stock and bond markets, this guarantee mitigates settlement risk by ensuring that sellers receive the funds they are due and buyers receive the securities they purchased. A CCP can make a market more liquid by allowing buyers and sellers to focus on the prices at which they trade, rather than which counterparties are most likely to fulfill the terms of the deal.

The CCPs serving the U.S. stock and bond markets ${ }^{6}$ guarantee obligations only between their members, typically broker-dealers where ordinary investors hold accounts. If a customer at one brokerage buys a stock from a customer at a second brokerage, money must move from the first brokerage to the second and shares from the second brokerage to the first. The CCP's guarantee applies to the movement of money and shares between member brokerages but not to the customers' original trade. Further, if one customer buys a stock while another customer at the

\footnotetext{
${ }^{4}$ See, for example, McCabe (2021) and Robinhood (2021).

${ }^{5}$ As discussed below, although a brokerage could conceivably charge fees to its customers for settlement risk, it could be difficult in practice to set such fees high enough to cover the brokerage's clearinghouse margin calls.

${ }^{6}$ The cash securities CCPs in the United States are NSCC, for stocks, corporate and municipal debt, American depositary receipts, exchange-traded funds, and unit investment trusts, and the Fixed Income Clearing Corp. (FICC), for U.S. government securities and mortgage-backed securities. NSCC and FICC are subsidiaries of the Depository Trust \& Clearing Corp. (DTCC).
} 
same brokerage sells it, the net amount the brokerage must deliver to other brokerages is reduced. Thus, when many trades take place at a brokerage, the risk to the $\mathrm{CCP}$ and the resulting collateral requirement depend on the net value of all the trades. Collateral therefore is an obligation of the brokerage, not its customers, and cannot be attributed to any particular customer trade. This system of guaranteeing and margining brokerages' obligations to each other, but not customers' individual obligations, is what lets customers avoid paying the full cost of settlement risk for some trades.

CCPs also serve markets for derivatives such as commodity and financial futures, interest rate and credit default swaps, and stock options. Futures and swaps CCPs in the United States handle customer trades differently from the CCPs in the cash securities markets. ${ }^{7}$ Although most traders in futures and swaps markets are not CCP members and must access the CCP through a member firm, the CCP keeps separate track of each trader's portfolio and assigns a collateral obligation to each trader. Each trader, whether a CCP member or a member's customer, therefore bears the cost of managing the risk of loss associated with their own portfolio. ${ }^{8}$ The externality is eliminated. In the market for stock options, a slightly different method removes the externality. Like futures customers, options customers are required to post collateral on their positions, but some options collateral remains at brokerages rather than being sent to the CCP.

The different treatment of customer trades at derivatives CCPs suggests a possible strategy for eliminating the customer settlement risk externality in securities markets: Cash securities CCPs could guarantee customer trades and collect collateral for them on a gross rather

\footnotetext{
${ }^{7}$ Futures and swaps CCPs in the United States include, among others, CME Clearing, for commodity and financial futures and interest rate swaps, and ICE Clear Credit, for credit default swaps. Equity options, though they are derivatives, are treated as securities in the U.S. regulatory framework; the CCP for this market is the Options Clearing Corp. (OCC).

${ }^{8}$ In addition to settlement risk, CCPs in derivatives markets mitigate credit risk over the potentially years-long duration of a derivatives contract.
} 
than net basis. Besides passing the costs of risk management through to customers, such a policy would mitigate some risks for the financial system. It would remain possible to conduct the actual transfers of cash at settlement on a net basis between brokerages, preserving one key benefit of the current netting system. However, guaranteeing and margining customer trades on a gross basis could have large operational costs given the large number of retail participants in the equity market, could require more assets to be posted as collateral at the CCPs, and could change the competitive balance between different types of brokerages. Alternatively, the CCPs could continue to guarantee and margin customer trades on a net basis, but with customers posting collateral to their brokerages on a gross basis, similar to the approach in the options market. Either approach would also require changes in regulations.

The CCP treatment of customer trades matters beyond the equity market. At present, customers generally trade U.S. Treasury securities only with their own dealers (Treasury Market Practices Group, 2019). Customer Treasury trades thus create no net obligation of one dealer to another and do not pass through the CCP. Duffie (2020) and Liang and Parkinson (2020) observe that if the CCP stood in the middle of dealer-to-customer trades, as it already does for interdealer trades, then a dealer that buys a security from its customer and sells the same security to another dealer would have no net obligation on its own account to the CCP. Duffie (2020) and Liang and Parkinson (2020) thus suggest than an expansion of Treasury clearing to customer trades might free dealers' balance sheet capacity for additional trading and make the market more liquid, as well as enable more "all-to-all" trading between customers. The analysis in this paper indicates that guaranteeing and margining customer trades on a gross rather than net basis would be critical for realizing the potential benefits of expanded Treasury clearing. To remove customer trades from dealer balance sheets, the CCP would need to guarantee customer trades on a gross 
basis. At the same time, because customers currently trade mostly with their own dealers, the dealers can currently account for risk management costs in setting a price. If all-to-all Treasury trading increased, margining customer trades on a gross basis would be important to prevent externalities in settlement risk management.

The paper proceeds as follows. Section 2 describes the current mechanics of central counterparties in the securities and derivatives markets, highlighting the differential effects of net and gross guarantees and margins for customer trades. Section 3 examines in more detail the implications of net and gross guarantees and margins for customer trades in the Treasury market. Section 4 discusses potential benefits and costs of a transition to guaranteeing and margining customer trades on a gross basis in the securities markets. Section 5 concludes and discusses how gross guarantees and margins could complement a move to faster securities settlement.

\section{Mechanics of net and gross CCP guarantees and margins for customer trades}

As discussed above, CCPs step into the middle of contracts in a financial market to provide each market participant with a guarantee that their counterparties will fulfill their contractual obligations. To provide this guarantee, CCPs use three main tools: membership requirements, novation, and margining. All three tools are at play in the customer settlement risk externality.

CCPs transact directly with only a limited number of carefully vetted market participants, known as CCP members. These firms must meet membership requirements, such as minimum capital levels and other risk management standards, and have the potential responsibility to share in losses if another member defaults and collateral is insufficient to cover the loss. Most market participants are not CCP members but instead interact indirectly with the CCP, as customers of 
its members. Unlike members, customers do not have loss-sharing obligations to the $\mathrm{CCP}$, but typically must compensate members for the services they provide. ${ }^{9} \mathrm{CCPs}$ require their members to cover customers' obligations if the customers default.

Novation is the legal action by which a CCP steps into the middle of contracts, becoming buyer to every seller and seller to every buyer, so that traders can count on the CCP to perform on their contracts and need not be concerned with the reliability and creditworthiness of their original counterparties. For example, novation replaces a contract requiring Buyer to pay $\$ 14$ per bushel to Seller for 5,000 bushels of soybeans with one contract requiring Buyer to pay the CCP for soybeans and a separate contract requiring the CCP to pay Seller for soybeans.

Margining is how the CCP covers the risk that one of the traders will default on the contract, which would make it costly for the CCP to fulfill the contract with the other trader. For example, if Buyer does not pay the amount owed, the CCP will have to accept Seller's soybeans and sell them in the open market. If the market price has fallen in the meantime to $\$ 13$ per bushel, the CCP will lose $\$ 5,000$. To protect itself, when the contract is novated, the CCP requires the participants to provide collateral that can be used to cover losses from future price changes. This collateral is sometimes called initial margin or performance bond. The CCP returns participants' collateral after they fulfill their contractual obligations. ${ }^{10}$

For CCP members, novation and margining work similarly in cash securities markets and derivatives markets in the United States. In both types of markets, members' obligations to other members are novated to the $\mathrm{CCP}$, and members post margin to the $\mathrm{CCP}$ to cover the risk of

\footnotetext{
${ }^{9}$ Even when CCP members do not charge explicit fees, customers can still face implicit costs such as below-market interest rates on cash balances. Customers may also receive clearing services from a CCP member as part of a larger package of services.

10 The CCP can typically call for additional initial margin during the life of a contract if risks change. CCPs also use many other tools to mitigate risk, such as mark-to-market payments, sometimes called variation margin, that prevent a buildup of obligations as prices move over time. These other tools are beyond the scope of this discussion.
} 
Table 1: Netting of a member's trades.

\begin{tabular}{|c|c|c|c|c|c|}
\hline Buyer & Seller & $\begin{array}{r}\text { Shares from } \\
\text { Member A }\end{array}$ & $\begin{array}{r}\text { Shares to } \\
\text { Member A }\end{array}$ & $\begin{array}{l}\text { Cash from } \\
\text { Member A }\end{array}$ & $\begin{array}{r}\text { Cash to } \\
\text { Member A }\end{array}$ \\
\hline Member A & Member B & & 500 & $\$ 1,000$ & \\
\hline Member C & Member A & 400 & & & $\$ 802$ \\
\hline Total & & 400 & 500 & $\$ 1,000$ & $\$ 802$ \\
\hline Net & & 0 & 100 & $\$ 198$ & $\$ 0$ \\
\hline
\end{tabular}

default on these obligations. Also, in both types of markets, if a member makes similar trades with more than one other member, the CCP nets down the similar trades and bases the margin requirement on the member's net obligations. For example, if member A buys 500 shares of a stock from member B for $\$ 1,000$ and sells 400 shares of the same stock to member $\mathrm{C}$ for $\$ 802$, then - as illustrated in Table 1 -member A must pay the CCP $\$ 198$ and receive 100 shares of the stock, and the margin requirement is based on the net obligations for $\$ 198$ and 100 shares.

What differs between securities and derivatives markets is the treatment of trades by members' customers. In the futures and swaps markets in the United States, ${ }^{11}$ customers are treated as beneficiaries of trades conducted on their behalf by clearing members, distinct from any trades that the clearing members conduct for their own accounts. Each customer's contracts are separately novated to the CCP. ${ }^{12}$ The Commodity Futures Trading Commission (CFTC), which regulates futures and swaps, also requires CCPs in these markets to collect customer margin on a gross basis and to segregate customer margin from the margin on clearing members' own portfolios. ${ }^{13}$ The CCP keeps separate records of the positions of each customer and each member and calculates the margin requirement separately for each trader's portfolio. ${ }^{14} \mathrm{~A}$

\footnotetext{
${ }^{11}$ Rules differ in some foreign jurisdictions.

${ }^{12}$ Formally, what is novated to a futures CCP when two customers trade is a contract between the customers' respective clearing members, but this contract is for the benefit of the two customers and is kept separate from contracts made by the clearing members themselves. See Steigerwald (2015) and references therein.

13 The CFTC and the Securities and Exchange Commission jointly adopted the relevant regulations for certain products, such as security futures, that the two agencies jointly regulate.

${ }^{14}$ See 17 CFR $\$ 39.13(\mathrm{~g}) 8(\mathrm{i})$.
} 
clearing member collects the required margin from each of its customers and remits the margin to the $\mathrm{CCP}$, along with any margin required for trades the member has made on its own account. The CCP holds customers' margin in a separate account from the margin for members' "house" trades, ${ }^{15}$ so that customers' margin essentially remains their own property. The only netting that takes place is within each customer's account, such that if a customer makes two trades with offsetting risks, the margin requirements for the two trades may partially cancel out.

The Securities and Exchange Commission (SEC), which regulates the markets for stocks, bonds, and equity options, does not require CCPs in these markets to collect customer margin on a gross basis. The CCPs for stocks and bonds have chosen to collect margin on a net basis and to guarantee transactions only between their members. If a customer at one brokerage buys a stock from a customer at a different brokerage, the two customers do not directly exchange money and shares. Rather, they give their money and shares to their brokers, which complete the transaction. ${ }^{16}$ In other words, the trade between the two customers gives rise to a transaction between their brokers. The transaction between brokers is novated to and guaranteed by the CCP, but not the legs between customers and their brokers, as shown in Figure $1 .{ }^{17}$

\footnotetext{
${ }^{15}$ See 17 CFR $\$ 1.20(\mathrm{~g}) 5(\mathrm{ii})$.

${ }^{16}$ In practice, investors in the United States typically do not directly own shares of stock. Rather, the registered owner of most stock shares and corporate and municipal bonds in the United States is Cede \& Co., a corporate nominee of the Depository Trust Co. (DTC), which is itself a subsidiary of DTCC. DTC's records assign shares to brokerages, and the brokerages' records assign shares to specific investors who are the beneficial owners of the shares. This system of holding shares in "street name" greatly simplifies settlement: While money must change hands, the movement of shares consists simply of entries on DTC's and the relevant brokerages' records, without any change in registered ownership. See Morris and Goldstein (2010).

${ }^{17}$ See National Securities Clearing Corp. (2021), Rule 11, section 1(b); Fixed Income Clearing Corp. (2021a), Rule 5, section 8; Fixed Income Clearing Corp. (2021b), Rule 5, section 13.
} 
Figure 1: The movement of cash and shares and the CCP guarantee in stock transactions.

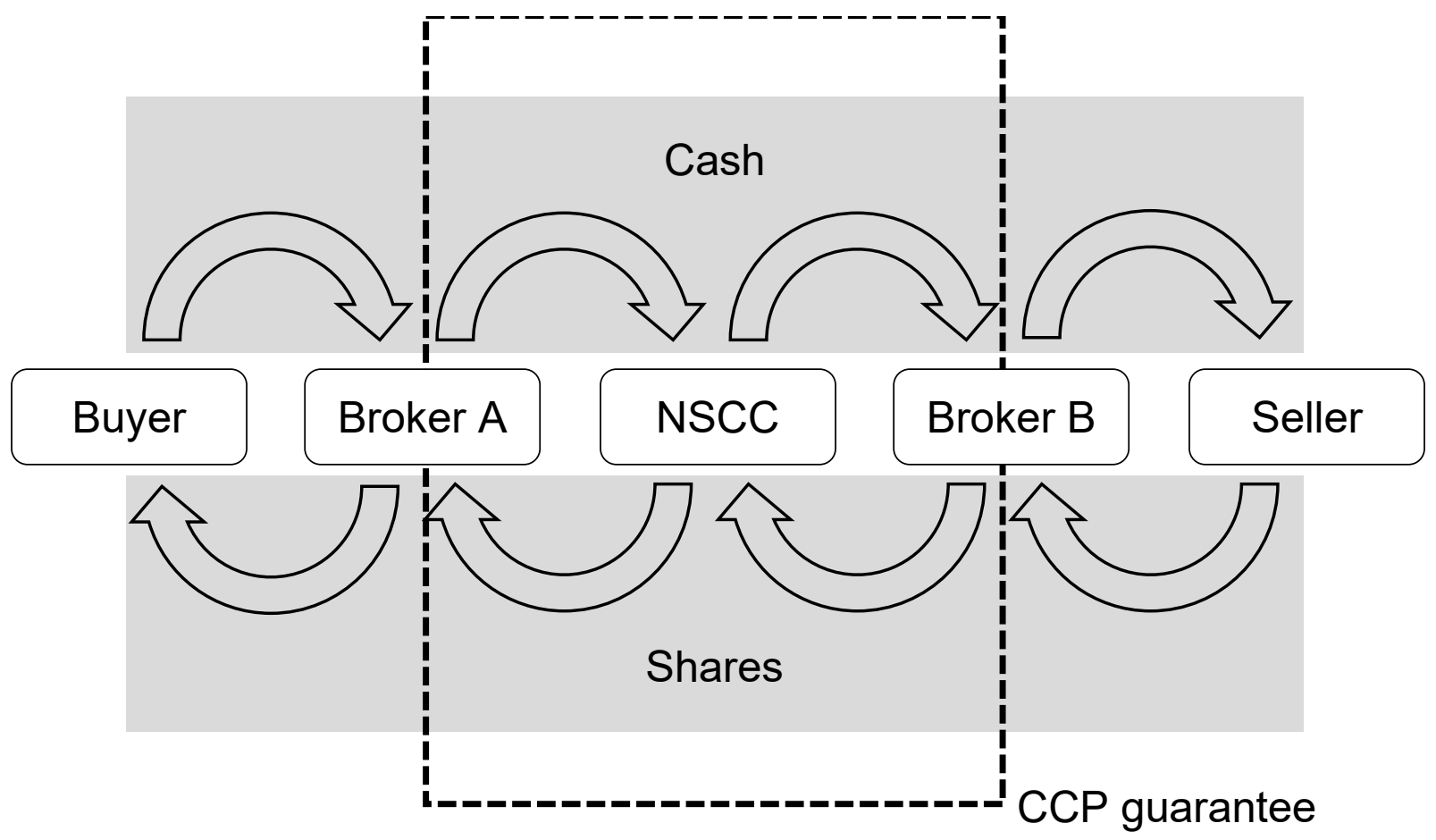

An added complication is that securities transactions at a given broker do not all come from the same customer. There are trades from many different customers, and potentially trades that the broker makes for its own account as well. In a cash securities CCP, all of these trades are aggregated to compute a member's net position at the CCP and the member's collateral requirement. ${ }^{18}$ Suppose that, as illustrated in Table 2, member A not only buys 500 shares of a stock from member B for $\$ 1,000$ and sells 400 shares of the same stock to member $\mathrm{C}$ for $\$ 802$, but also has one customer who buys 100 shares from a customer of member D for $\$ 202$ and another customer who sells 200 shares to a customer of member $E$ for $\$ 400$. On net, these trades add up to 0 shares and $\$ 0$. Member $A$ has no net position with other members and no net position at the $\mathrm{CCP}$ in regard to this stock, and no margin is due from member A.

\footnotetext{
${ }^{18}$ See National Securities Clearing Corp. (2021), Rule 11, section 1(a), and Procedure XV; Fixed Income Clearing Corp. (2021a), Rules 1 and 4; Fixed Income Clearing Corp. (2021b), Rules 1 and 4.
} 
Table 2: Netting of a member's trades and its customers' trades.

\begin{tabular}{llrrrr} 
Buyer & Seller & $\begin{array}{r}\text { Shares from } \\
\text { A and its } \\
\text { clients }\end{array}$ & $\begin{array}{r}\text { Shares to A } \\
\text { and its } \\
\text { clients }\end{array}$ & $\begin{array}{r}\text { Cash from A } \\
\text { and its } \\
\text { clients }\end{array}$ & $\begin{array}{r}\text { Cash to A } \\
\text { and its } \\
\text { clients }\end{array}$ \\
\hline $\begin{array}{l}\text { Member A } \\
\text { Member C }\end{array}$ & $\begin{array}{l}\text { Member B } \\
\text { Member A }\end{array}$ & 400 & 500 & $\$ 1,000$ & \\
$\begin{array}{l}\text { A's customer } \\
\text { E's customer }\end{array}$ & $\begin{array}{l}\text { D's customer } \\
\text { A's customer }\end{array}$ & 200 & 100 & $\$ 202$ & $\$ 802$ \\
\hline $\begin{array}{l}\text { Total } \\
\text { Net }\end{array}$ & & 600 & 600 & $\$ 1,202$ & $\$ 1,202$ \\
& & 0 & 0 & $\$ 0$ & $\$ 0$
\end{tabular}

The net approach to novating trades and collecting margin for securities transactions means that one cannot attribute any specific part of the margin requirement to any particular customer's unsettled trades. Because margin is a function of all the trades at a brokerage, and because only the brokerage's obligations to other brokerages are novated to the CCP, the margin requirement is an obligation solely of the brokerage and not of its customers. Furthermore, the SEC and CFTC require brokerages to protect their customers by keeping the customers' money in separate accounts. ${ }^{19}$ A brokerage cannot count margin posted at the CCP for customers' stock and bond purchases and sales as protected customer funds, ${ }^{20}$ because the margin is an obligation of the brokerage and not its customers. Thus, even if a brokerage could attribute the net margin requirement for stock and bond transactions to specific customers, it could not use the customers' funds to post margin — the margin must come from the brokerage's own funds. This restriction flows logically from the idea that only obligations between brokerages are novated to the $\mathrm{CCP}$ and from the policies that protect customer funds, but it is a further obstacle to passing the costs of risk management through to customers.

\footnotetext{
${ }^{19}$ See 17 CFR $\$ 1.20(a)$ and 17 CFR $\$ 240.15 \mathrm{c} 3-3(\mathrm{e})$.

${ }^{20}$ See 17 CFR $\$ 240.15 \mathrm{c} 3-3 \mathrm{a}$.
} 
Equity options, cleared at the Options Clearing Corp. (OCC), are an intermediate case between gross and net customer margining. OCC calculates margin on equity options separately for a member's own trades and for the net value of customer trades at the member. ${ }^{21}$ Customer activity at a member can be divided into multiple accounts, for example in order to isolate activity by market-makers, which have unusually complex portfolios, and to protect customers holding long options positions, which do not require initial margin. ${ }^{22}$ In addition, collateral can be posted for specific customer trades, which are then excluded from the margin calculation. ${ }^{23}$ Furthermore, funds posted at OCC as margin for customer trades count toward the brokerage's obligation to segregate and protect customer funds, ${ }^{24}$ and Federal Reserve regulations require a brokerage to collect margin from each of its customers for their options trades. ${ }^{25}$ The ultimate effect of these rules is that customers bear the costs of risk management for typical options portfolios, similar to the gross margin system for futures and swaps, even though OCC calculates customer margin on a net basis. However, some of the customers' margin is held at their brokerages rather than at the $\mathrm{CCP}$, and the margin that customers post to their brokerages is calculated with a different model than the one used to determine brokerages' margin obligations at the $\mathrm{CCP} .{ }^{26}$

The markets' differing methods of novating and margining customer trades create different incentives for customers. In the futures and swaps markets, and to a substantial degree

\footnotetext{
${ }^{21}$ See Options Clearing Corp. (2021), Rule 601.

${ }^{22}$ See Options Clearing Corp. (2021), Rule 611, and Options Clearing Corp. (2020a), Article VI, section 3.

${ }^{23}$ See Options Clearing Corp. (2021), Rules 601(c), 610, 610A, 610B and 610C.

${ }^{24}$ See 17 CFR $\$ 240.15 \mathrm{c} 3-3 \mathrm{a}$.

${ }^{25}$ See 12 CFR Part 220. Margin can be collected separately for each options position that a customer holds based on a regulatory formula, a method known as Regulation T margin, or can be computed for the customer's entire portfolio based on rules adopted by a securities self-regulatory organization and approved by the SEC, a method known as portfolio margin.

${ }^{26}$ See Options Clearing Corp. (2020b), Principle 6, Key Consideration 1, for the CCP margin model and Securities and Exchange Commission (2006), footnote 16, for the customer portfolio margin model.
} 
in the options market, customers directly bear the cost of risk management for their own positions. A derivatives portfolio that entails greater risks, such as a position in a volatile market, requires the customer to post more margin, and the customer must consider this cost in deciding whether to trade. On the other hand, when margin requirements are high, derivatives customers who can meet those requirements can generally continue to trade. They do not need to worry that their clearing member will reject trades just because the clearing member does not want to post the margin for those trades. (A derivatives clearing member might still stop a customer from trading if the member feared that the customer would default and leave debts in excess of posted margin, which the clearing member would have to cover.) In the cash securities markets, by contrast, while a brokerage can use fees or other methods to recoup the average cost of posting margin for customer trades, there is generally no additional cost to the customer for a trade that requires unusually high margin. (Just as in derivatives, however, the brokerage might set risk limits for customers that it fears may default.) Cash securities customers who make trades with unusually high settlement risk, such as when prices are moving rapidly, do not pay the cost of managing this risk. If they are allowed to trade, they may ignore the risk management cost and leave their brokers to absorb it. In consequence, brokers may find it in their best interest to refuse these customer trades.

Conceivably, instead of refusing trades, a broker could try to impose risk management costs on customers. The broker could, for example, require its customers to post collateral to the broker to cover settlement risk. Customers would then be aware of the risk management costs of their portfolios of unsettled trades. However, the broker would still need to use its own funds to post margin to the CCP, so the broker still might not want to accept some trades, and risk 
management costs for any accepted trades would now be paid twice- by the broker and by the customer.

Alternatively, the broker could seek to recoup its costs by charging higher commissions for trades that create high risk management costs. However, rapidly changing the commissions charged for some trades but not others might be operationally difficult. In addition, risk management costs depend on the interactions between all of a customer's unsettled trades, so it could be difficult to determine the appropriate charge for any individual trade that a customer makes. For example, the change in CCP margin that will result from a particular trade depends on whether any offsetting trades take place the same day. (Related, a broker that wanted to collect margin for securities settlement from its customers or charge them for settlement risk management costs would need to build a system for calculating these costs for each trade, since the CCP provides a calculation only for the broker's net obligations. It may be easier to determine that a trade is too costly and refuse it than to estimate the cost with enough precision to align customers' incentives.) Also, when a customer pays a commission to a broker, the customer permanently loses the amount of the commission, whereas collateral is refunded when the trade settles. Because collateral is refunded at settlement, the cost of posting collateral can be thought of as approximately two days' interest on the amount posted. If the broker charged customers a fee equal to the full amount of collateral due to the CCP, this would far exceed the actual cost of posting margin. But if the broker collected less than the full amount of margin as a fee, the broker would still need to use its own funds to post margin and could have difficulty obtaining the required liquidity. 


\section{Net clearing, gross clearing, and the Treasury market}

The stock market is an "all-to-all" market. Investors can trade shares on an exchange with anyone else who wants to trade, whether that counterparty is a broker-dealer or another investor and no matter where the counterparty holds an account. The market for Treasury securities works very differently. Dealers that are members of the CCP (the Fixed Income Clearing Corp., or FICC) trade Treasuries with each other, either directly or through interdealer brokers (IDBs). IDBs are also members of the CCP. Other market participants, such as institutional investors and principal trading firms, generally trade Treasuries over the counter with dealers where they are customers or on IDB platforms. IDBs often create anonymous trading platforms, similar to a stock exchange, that produce a form of all-to-all trading. However, ordinary investors generally cannot directly access these platforms, most activity on them is in the most recently issued securities, and transactions on these platforms take the form of the buyer and seller each transacting with the IDB rather than directly with each other. As IDBs and some participants on their platforms are $\mathrm{CCP}$ members while other participants on these platforms are not CCP members, transactions on IDBs result in a mixture of central and bilateral clearing. ${ }^{27}$

A consequence of this market structure is that trades involving non-members are not currently cleared. Why? The CCP guarantees each member's obligation to other members. A non-member's trade with a CCP member does not affect the member's obligation to other members. And in the Treasury market, non-members generally trade only with CCP members, not with other non-members. (A trade between two non-members through an IDB results in two transactions with the IDB and no net obligation of the IDB to the CCP or other CCP members.)

\footnotetext{
${ }^{27}$ Treasury Market Practices Group (2019) provides additional detail on Treasury market structure.
} 
Another consequence of this market structure is that clearing non-members' Treasury trades would require the CCP to margin customers' trades separately from their dealers' trades, either through margining customer trades on a gross basis or through separate accounts for customer trades and dealers' house trades, similar to the approach at OCC. If the CCP nets all trades at a dealer before calculating margin, as at present, customer trades with their own dealers generate no margin requirement and are not collateralized at the CCP. In consequence, if customer-to-dealer trades were novated to the CCP in the present system, the CCP would have no protection against customer defaults other than the dealer's own guarantee of its customers' obligations. This would make it difficult for customer-to-dealer trades to be cleared at the CCP and potentially netted against the dealer's interdealer position and removed from the dealer's balance sheet.

Why is clearing much broader in the equity market than the Treasury market even though the equity and Treasury CCPs both guarantee and margin only interdealer obligations? The answer goes back to market structure. In equities, all-to-all trading on exchanges makes it common (though not universal) for the two sides of a trade to involve investors that are customers at different CCP members. Such trades are cleared because they create an obligation between the two investors' clearing members. In other words, in the equity market, all-to-all trading results in broad clearing of customer trades; it does not appear to be the clearing architecture, which is very similar to Treasuries, that causes all-to-all trading.

Nevertheless, there is a potentially important interaction between all-to-all trading and the current clearing system in the Treasury market. If all-to-all Treasury trading were to expand beyond its current limited scope on IDBs, but the market retained a net approach to customer clearing, then Treasury customers could trade with each other and impose costs of managing 
unusually elevated settlement risk on their dealers. That is, the same settlement risk externality would arise that is present in the equity market. Clearing customer trades on a gross basis would allow all-to-all Treasury trading to expand without creating externalities in settlement risk management. $^{28}$

\section{Potential benefits and costs of gross customer clearing in securities markets}

Gross margining of customer securities trades would effectively require customers to make down payments on the day that they enter trades, as a safeguard against the risk of defaulting when the full value is settled two days later. For example, a buyer might pay a few percent of the purchase price on the trade date, and the rest at settlement. (For a customer with two or more unsettled transactions, margin would be based on the combination of transactions, not on each transaction individually.) Regulations would need to be changed to count funds posted at cash securities CCPs as protected customer funds. Because the margin payment would count toward the purchase price, the cost to the customer of posting margin would not be the full amount of margin posted, but just the time value of paying that money on the trade date rather than the settlement date. If the customer already had settled funds in their account, it would be costless to pay some (or all) of the purchase price on the trade date. Many of the potential benefits of novating and margining customer trades on a gross basis would come from the incentive the gross system would create for customers to act in ways that minimize the costs of posting margin up front. Simultaneously, many of the costs would come from requiring more margin than in a net system.

\footnotetext{
${ }^{28}$ This paper focuses on the risk of loss of value. CCPs also have costs of managing liquidity risk, that is, the risk of needing to convert securities to cash to be able to make required payments in the event of a member default. The incidence on members and customers of the CCP's costs of managing liquidity risk is beyond the scope of this paper.
} 
An alternative to novating and margining customer trades on a gross basis would be to use a hybrid system along the lines of that used for equity options. The clearinghouse could segregate customer and house positions of each brokerage so that customer obligations could be clearly identified and so that posting customer funds as CCP margin on customer trades would not commingle customer and house assets and obligations. The clearinghouse could also allow the segregation of some customer positions from others to further protect customers from each other or could allow the posting of customer assets to collateralize specific customer trades, and brokerages could collect margin on gross customer trades while posting only net margin to the CCP. As in the case of equity options, such a system would largely replicate the effects of clearing customer trades on a gross basis.

\section{A. Benefits}

Putting a price on settlement risk: As discussed, gross customer margining in securities markets would ensure that customers bear the costs of risk management for the settlement of each of their trades and therefore help ensure that the volume of trading is efficient. In particular, there would be a disincentive to trade at times when settlement risks are especially high, such as when markets are unusually volatile. This change in incentives could reduce the aggregate settlement risk in the financial system at volatile times, though at the potential cost, discussed below, of reducing market liquidity in some instances. Simultaneously, there would be less reason for brokerages to shut down trading if they cannot or do not want to pay the cost of margin for customer trades, so long as the customers themselves were willing and able to pay the cost. Further, as the current system effectively asks customers to pay an average cost of settlement risk for every trade, there could be some scope for lowering customer costs of trades 
with below-average settlement risk — though many costs besides settlement risk would continue to influence customers' costs of trading.

Reducing hidden leverage: Regulations limit investors' ability to borrow money to buy stocks, as well as limit the use of options, which have embedded leverage. However, securities purchases can create a hidden form of leverage in a customer's account during the settlement period even when the customer is not technically borrowing. For example, if a customer buys shares of stock, they have two business days to provide the funds for the purchase. Some brokerages require a customer to have settled funds in their brokerage account before making a purchase, but others may allow some customers to provide the funds by selling other, previously settled shares in their account later on the same day (so that the purchase and sale will settle simultaneously) or by wiring money from a bank account. If the customer wires the money one day after the trade, this will meet the settlement deadline (two days after the trade) and thus is not considered to involve purchasing on credit. Nevertheless, the brokerage effectively is providing credit to the customer in the amount of the margin due to the $\mathrm{CCP}$ because the brokerage bears the settlement risk until the customer's wire transfer arrives. This hidden leverage could lead to unexpected losses in a volatile market. If customer trades were novated and margined on a gross basis, customers would have to post margin on the trade date, eliminating the hidden leverage.

Lower balance sheet costs for dealers: In the current system, dealers' unsettled trades with their own customers are not cleared and remain on the dealers' balance sheets. Duffie (2020) and Liang and Parkinson (2020) argue in the context of the Treasury market that dealers may need to hold capital against these trades to comply with regulations or address internal risk management concerns, and that the cost of capital could limit dealers' willingness or ability to 
intermediate for their customers. If customer trades were novated to the CCP on a gross basis, a dealer's unsettled trades with its customers could be netted against its unsettled trades with other dealers, potentially reducing balance sheet costs for the dealer. Still, as discussed below, any reduction in dealer balance sheet use comes at a cost: Novating and margining customer trades on a gross basis requires more resources to be posted as collateral at the $\mathrm{CCP}$ in that $\mathrm{CCP}$ margin requirements increase for formerly offsetting trades by customers at the same brokerage.

Competitive effects: With net margining, margin is the obligation of the clearing member rather than its customers. This obligation may be easier to meet for clearing members that face a lower cost of capital, such as those with higher credit ratings. In addition, for a given total amount of customer trading, a clearing member's margin obligation is higher when its customers tend to make similar trades than when its customers tend to make offsetting trades. Large clearing members with diversified customer bases (whose trading may be more heterogeneous) thus may face lower costs in the current system. A transition to gross customer margining could reduce this advantage and might thereby increase competition among brokerages, which could benefit customers. As noted below, competitive changes could also have drawbacks.

\section{B. Costs}

Novating and margining customer trades on a gross basis would have several costs that would need to be weighed against the potential benefits.

Transition and operational costs: CCPs and their members would need information systems capable of calculating each customer's margin requirement, collecting the requisite funds from each customer on the trade date and returning them upon settlement, and keeping track of customer ownership of funds posted to the CCP as margin. The implementation and 
operation of such systems could be costly, especially given the large number of retail investors in the equity market. Such systems already exist for exchange-traded futures, but fewer investors trade futures than equities. In 2011, when the CFTC adopted its current margin rules for futures, it decided that the benefits of a transition to gross margining outweighed the operational costs for futures CCPs that were then allowing some netting across customers. ${ }^{29}$

Liquidity costs: Net margining uses liquidity in the financial system more efficiently than gross margining because, under net margining, many trades do not have to be margined at all. Gross customer margining would require cash securities CCPs to collect margin on all trades, not just net trades at each member. To precisely estimate how much additional margin would be required, one would need data on all trades in the relevant markets. The amount is likely to be substantial. NSCC, for example, reports that netting reduces transaction volumes by $98 \%$ (Depository Trust \& Clearing Corp., 2021). If the margin savings from netting are similar to the transaction volume savings, then gross margining at NSCC could require a 50-fold increase in margin from the $\$ 9.3$ billion that NSCC reported as of Sept. 30, 2020, the most recent available (Depository Trust \& Clearing Corp., 2020). These resources would have to be posted at the CCP rather than held elsewhere in the financial system and used for other purposes. Still, collecting this collateral is what produces the benefits of the gross system.

Novating more trades to the $\mathrm{CCP}$ could also require the $\mathrm{CCP}$ to have more liquid resources such as credit lines available to help manage member defaults. Again, estimating these needs would require detailed transaction data.

However, novating and margining customer trades on a gross basis would not require settlement of these trades to take place on a gross basis. The CCP could still compute the net

\footnotetext{
${ }^{29}$ See Commodity Futures Trading Commission (2011), pages 69374-69376.
} 
amount of cash and securities to be moved between member firms and settle all transactions at once by moving these net amounts. Thus, the liquidity savings from net settlement could be preserved even in a system of guaranteeing and margining gross customer trades.

Costs of participation and market liquidity: Because gross customer margining requires more margin to be posted, in the aggregate, than net customer margining, the gross system effectively raises the cost of participating in the market. This higher cost might be viewed as detrimental to customers in and of itself. In addition, increased trading costs could make markets less liquid. However, the cost of margining imposed on securities customers would typically be small. A customer buying a security would be required to have a fraction of the purchase price in settled funds in their brokerage account on the day of the trade instead of delivering all the funds two days later, for example. In addition, to the extent that customers do not currently pay the full cost of settlement risk on some trades, raising the cost on these trades would lead to a more efficient outcome.

Competitive effects: As noted above, a transition to gross customer margining could reduce the current potential advantage of clearing members that have low costs of capital and large, diversified customer bases. Although this could make the market for brokerage services more competitive, it might also weaken the clearing ecosystem if CCPs became more reliant on smaller, less creditworthy members or ones whose customers have a greater tendency toward herding. However, if necessary, CCPs could strengthen their membership requirements to address this risk. 


\section{Conclusion}

This paper examines an externality in the current system for managing settlement risk on securities trades. Solutions to that externality could also complement faster, but not instantaneous, securities settlement. Settling equity trades in one business day rather than two, as the CCP recently proposed (Depository Trust \& Clearing Corp., 2021), would reduce settlement risk because there would be less time for prices to move between trade and settlement. But some settlement risk would remain, and under the current architecture, the externality would remain as well. Even with faster settlement, guaranteeing and margining customer trades on a gross basis would have the benefit of eliminating the externality and the associated risks. At the same time, because faster settlement reduces settlement risk, less collateral would be required, and the liquidity cost of gross margining would be reduced. If the market moved to real-time settlement of securities trades, settlement risk and the associated externality would be eliminated. But realtime settlement would entail many other risks and costs (Monahan, 2019; Depository Trust \& Clearing Corp., 2021).

CCPs are sometimes described as part of the "plumbing" of the financial system: infrastructure that is usually taken for granted, but crucial nonetheless. If CCPs are plumbing, their margin systems are one component of the plumbing - the valves, perhaps. Though margin systems are but one piece of the plumbing, their design can have noticeable practical effects, as recent stock market events have shown and as calls for further study of broader Treasury clearing have suggested. With the continued growth of central clearing in important financial markets worldwide, the specifics of CCP design deserve careful consideration. 


\section{References}

Banerji, Gunjan, Juliet Chung, and Caitlin McCabe. 2021. "GameStop Mania Reveals Power Shift on Wall Street - and the Pros Are Reeling." Wall Street Journal, January 27, available at https://www.wsj.com/articles/gamestop-mania-reveals-power-shift-on-wallstreetand-the-pros-are-reeling-11611774663?reflink=desktopwebshare permalink.

Committee on Payments and Market Infrastructures. 2016. "A glossary of terms used in payments and settlement systems." Available at https://www.bis.org/cpmi/publ/d00b.htm.

Commodity Futures Trading Commission. 2011. "Derivatives Clearing Organization General Provisions and Core Principles." Federal Register 76(216, November 8), 69334-69480.

Cox, Robert T., and Robert S. Steigerwald. 2017. "A CCP is a CCP is a CCP," Policy Discussion Paper 2017-01, Federal Reserve Bank of Chicago.

Depository Trust \& Clearing Corp. 2020. "Fixed Income Clearing Corporation and National Securities Clearing Corporation, Public Quantitative Disclosures for Central Counterparties, Q3 2020.” Available at https://www.dtcc.com//media/Files/Downloads/legal/policy-and-compliance/CPMI-IOSCO-QuantitativeDisclosure-Results-2020-Q3-1.pdf.

Depository Trust \& Clearing Corp. 2021. "Advancing Together: Leading the Industry to Accelerated Settlement," available at https://perspectives.dtcc.com/downloads/whitepaper/leading-the-industry-to-acceleratedsettlement.

Duffie, Darrell. 2020. "Still the World's Safe Haven? Redesigning the U.S. Treasury Market After the COVID-19 Crisis," Hutchins Center Working Paper No. 62, Brookings Institution.

Fixed Income Clearing Corp. 2021a. "Government Securities Division Rulebook," effective February 1, available at https://www.dtcc.com/ /media/Files/Downloads/legal/rules/ficc_gov_rules.pdf.

Fixed Income Clearing Corp. 2021b. "Mortgage-Backed Securities Division Rulebook," effective January 1, available at https://www.dtcc.com/ /media/Files/Downloads/legal/rules/ficc mbsd rules.pdf.

Liang, Nellie, and Pat Parkinson. 2020. "Enhancing Liquidity of the U.S. Treasury Market Under Stress," Hutchins Center Working Paper. No. 72, Brookings Institution.

McCabe, Caitlin. 2021. "Robinhood, Other Brokerages Restrict Trading on GameStop, AMC." Wall Street Journal, January 28, available at https:/www.wsj.com/articles/onlinebrokerages-restrict-trading-on-gamestop-amc-amid-frenetic-trading-11611849934.

Monahan, Ken. 2019. "Steampunk Settlement: Deploying Futuristic Technology to Achieve an Anachronistic Result." White paper, Greenwich Associates. Available at https://www.greenwich.com/market-structure-technology/steampunk-settlement.

Morris, Virginia B., and Stuart Z. Goldstein. 2010. Life Cycle of a Security. New York: Lightbulb Press.

National Securities Clearing Corp. 2021. "Rules \& Procedures," effective February 1, available at https://www.dtcc.com/ /media/Files/Downloads/legal/rules/nscc_rules.pdf.

Options Clearing Corp. 2020a. "OCC By-Laws,” available at https://www.theocc.com/getmedia/3309eceb-56cf-48fc-b3b3498669a24572/occ bylaws.pdf. 
Options Clearing Corp. 2020b. "The Options Clearing Corporation Disclosure Framework for Financial Market Infrastructures," available at https://www.theocc.com/getmedia/4664dece-7172-42a5-8f55-5982f358b696/pfmidisclosures.pdf.

Options Clearing Corp. 2021. "OCC Rules,” available at https://www.theocc.com/getmedia/9d3854cd-b782-450f-bcf733169b0576ce/occ rules.pdf.

Robinhood. 2021. "What happened this week," January 29, available at https://blog.robinhood.com/news/2021/1/29/what-happened-this-week.

Securities and Exchange Commission. 2006. "Self-Regulatory Organizations; Chicago Board Options Exchange, Incorporated; Notice of Filing of Amendment Nos. 1 and 2 to the Proposed Rule Change Relating to Customer Portfolio Margining; Order Granting Accelerated Approval to the Proposed Rule Change, as Amended.” Federal Register 71(242, December 18), 75781-75788.

Steigerwald, Robert S. 2015. "Central Counterparty Clearing and Systemic Risk Regulation.” In The World Scientific Handbook of Futures Markets, edited by Anastasios G. Malliaris and William T. Ziemba, chapter 7, pp. 181-246. Singapore: World Scientific Publishing.

Treasury Market Practices Group. 2019. "White Paper on Clearing and Settlement in the Secondary Market for U.S. Treasury Securities," available at https://www.newyorkfed.org/medialibrary/Microsites/tmpg/files/CS FinalPaper_071119. pdf. 